\title{
Development of Learning Instrument Based on Scientific Learning to Improve Students' Mathematical Problem Solving and Self-Regulated Learning Ability at MTs. Sinar Islami Bingai
}

\author{
Suhendro*, Edy Surya, Waminton Rajagukguk, Edi Syahputra \\ Mathematics Education, State University of Medan, Medan, Indonesia \\ *Corresponding author: hendrosuhendro27@gmail.com
}

Received August 14, 2018; Revised October 11, 2018; Accepted October 31, 2018

\begin{abstract}
This research aims to describe the valid, practical and effective learning instrument based on the scientific learning that has been developed and produce learning instrument for developing valid learning instrument based on a scientific learning to improve mathematical problem solving ability and self-regulated learning at MTs Sinar Islami Bingai. This research is a development research. The development model used is the 4-D model which consists of four stages: define, design, develop and disseminate. The research subject is a learning instrument of the discussion of one variable linear equations and inequalities. The development testing was carried out on class VII of MTs Sinar Islami Bingai. The first development testing is carried out in class VII-2 and The second development testing is carried out in class VII-1 MTs Sinar Islami Bingai. The results of obtained development are : (1) Learning instrument developed were valid; (2) The learning instrument developed practically were indicated by responses of validator who said that learning instrument could be used with little revision or without revision; (3) Effective learning instrument were indicated by classical student learning completeness that has been achieved, positive student response to the components of learning instrument and learning activities developed, and the ability of teachers to manage learning obtain an average good category score. Increased self-regulated learning reached an average of 79.09 in the first development testing and 82.35 in the second one.
\end{abstract}

Keywords: development of learning instrument, scientific learning, mathematical problem solving abilities, self-regulated learning

Cite This Article: Suhendro, Edy Surya, Waminton Rajagukguk, and Edi Syahputra, "Development of Learning Instrument Based on Scientific Learning to Improve Students' Mathematical Problem Solving and Self-Regulated Learning Ability at MTs. Sinar Islami Bingai.” American Journal of Educational Research, vol. 6, no. 10 (2018): 1430-1437. doi: 10.12691/education-6-10-14.

\section{Introduction}

The problem of education hasbeen always interesting topics of conversation, both in the teacher, parents and education experts.This is something understandable because every people wants the best education for students, children or for the next generation of this nation. Rajagukguk (2011) [1] said that the right education is education that prepares students to become quality human resources.The education process is carried out in such a way that humans can understand and appreciate the meaning of education so that it can be useful for themselves in living their lives.

The main objective of the learning process is to achieve the learning objectives and the goal is primarily for students' success in learning, both in a particular subject and in general education. Hosnan (2014: 7) [2] suggests that learning is essentially a process of interaction with all situations surrounding individual students.In the learning process sometimes there are learning problems that can lead to failure in the learning process. Surya, Sabandar, Kusumah, and Darhim (2013) [3] said The teachers' are concern in the problem or question in class which is done by teachers and students is become routine activity and must activity to do in the learning process to emphasis students more active to get involved in the process of knowledge delivery.

This means that the teacher's attention in the problem or question in the classroom conducted by the teacher and students becomes a routine activity in the teaching and learning process so students will more actively involved in the process of knowledge delivery. The low mathematics grade of students' learning result are indicated by failure of majority students caused by uncompletely achievement for minimal defined pass score.This is also reflected in the average class for mathematics subjects, absorbtive capacity and learning completeness of grade VII students of MTs Sinar Islami Bingai for the 2017/2018 school year 
is still low, for example 60 for class average, $60 \%$ for absorbtive capacity, and $65 \%$ for learning completeness. These data indicate that students' mathematics learning outcomes have not yet achieved as is expected by the curriculum, which is 65 for the class average, 65\% for absorbtive capacity and $85 \%$ for learning completeness.

Problem solving abilities are part of a very important mathematics curriculum and even become the main target in mathematics learning. This can be seen from the purpose of learning mathematics at the secondary education level as stated in the attachment of Permendikbud No. 59 (2014) [4] which contains skills or abilities that students must possess in learning mathematics. Eviyanti, Surya, Syahputra, and Simbolon (2017) [5] stated: To obtain the ability in problem solving, one must have a lot of various problems in solving problems. This means that to get the ability to solve problems, one must have a lot of experience in solving various problems. This idea supports the argument for using open problem. But in reality there are very few teachers who use problem solving in mathematics learning.

In addition to the importance of problem solving abilities in mathematics students also need to have an attitude of self-regulated learning. Suhery, Saragih, and Syahputra (2013) [6] suggested that the self-regulated learning became one of the important factors that determine the success of student learning, especially those related to the ability of students' mathematical problems. Therefore every teacher must be able to create learning situations that make students able to develop self-regulated learning well.

In fact, based on information from the mathematics teacher in class VII MTs Sinar Islami Bingai, students have not fully had the value of independence. This can be seen from the problems that happen including that students are not sure of their own abilities, students ask to be directed by the teacher continuously in learning activities, students need support from others who are excessive in solving their own problems, unable to learn independently, students carry out activities must be on the command of others, students often cheat on a friend's work when there is an assignment or when the test takes place, if there is homework rarely done, students use study time in school to play when there are empty hours, students do not have responsibility in carrying out tasks, and students always want to quickly end their learning activities.

There are many ways that can be carried out to develop learning instrument in this case. One of them is to use the Scientific learning. Atsnan and Gazali (2013) [7] suggests that the scientific approach or more generally said the scientific learning is an learning in the 2013 curriculum. Then Hosnan (2014: 34) [2] argued that the implementation of the 2013 curriculum in learning with a scientific approach is a learning process designed in such a way that students actively construct concepts, laws or principles. In Permendikbud No. 81 (2013) [8] A attachment four of the general guidelines for learning, it is stipulated that all fields of study are obliged to reproduce learning using a scientific learning. In connection with one essence of the 2013 curriculum, namely the scientific learning, there are science activities that students need to comprehanse, namely observing, asking, collecting information, managing information, and communicate them.Thus it can be concluded that the scientific learning is able to provide understanding to students in recognizing, understanding various materials using a scientific learning, that information can come from anywhere, at any time, does not depend on the direction of the teacher.Therefore learning conditions are directed to encourage students to find out from various sources through observation, and not just be told.

Based on the above result, the writer is interested in conducting a study related to the development of learning instrument in accordance with the conditions expected in the future.This research is entitled "Development of Scientific Learning Instrument Based to Improve Students' Mathematical Problem Solving and Self-Regulated Learning Ability at MTs.Sinar Islami Bingai".

\section{Method}

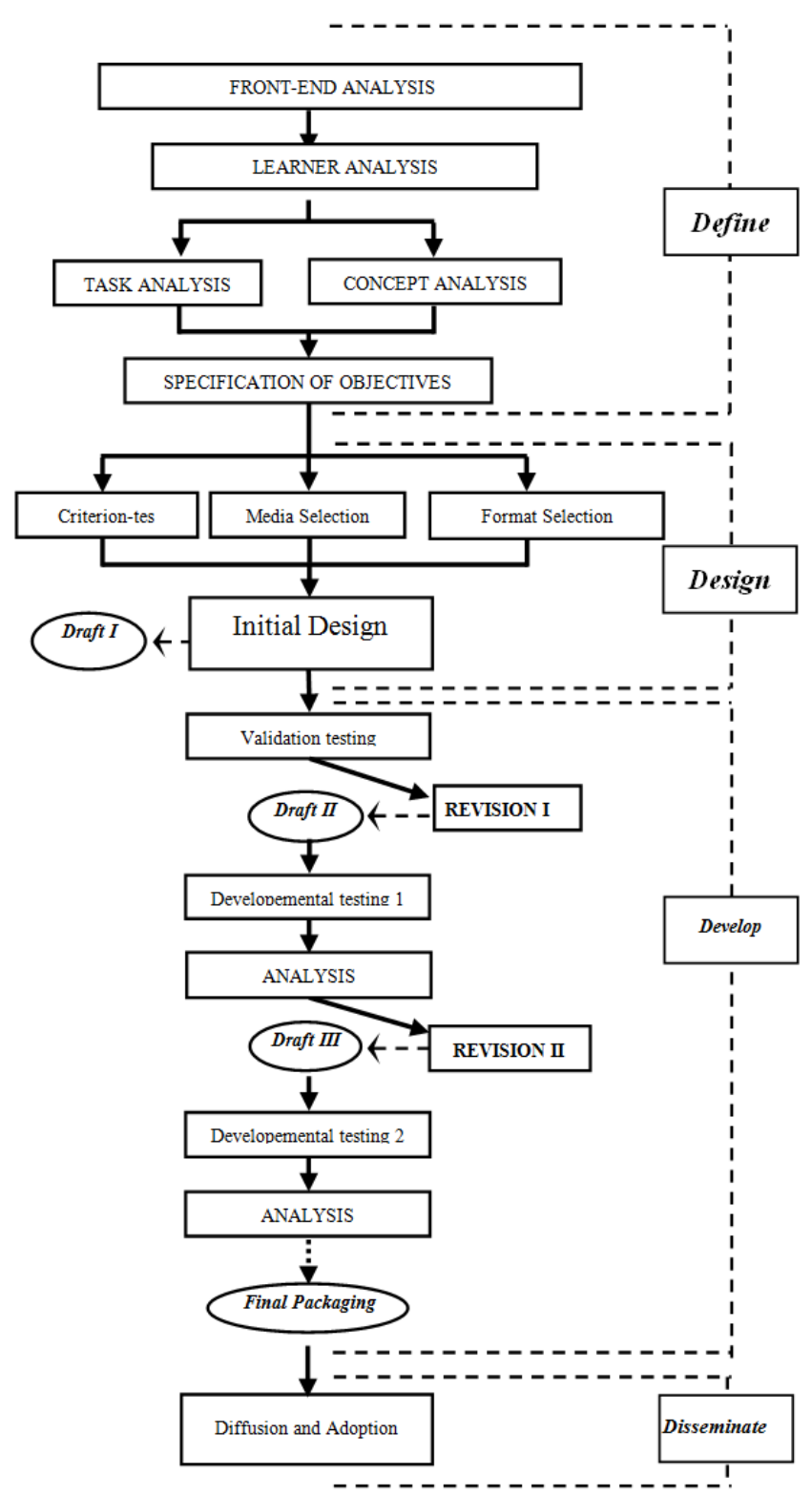

Explanation :

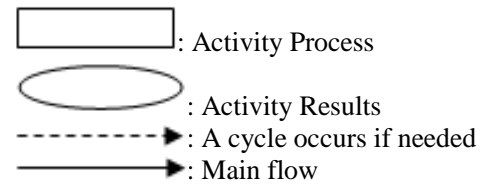

Figure 1. Development Chart of 4D Model For Intructional Development 
This research includes the development of learning instrument based on a scientific learning that refers to the Thiagarajan 4D model (1974). Which consists of four stages, they are define, design, develop, and the disseminate stage. The model of development in this study is systematically shown in Figure 1:

\subsection{Define}

\subsubsection{Front - End Analysis}

Front-End Analysis is to examine the junior high school mathematics curriculum that is used in the research location, so that a description of the learning patterns that are considered suitable are obtained. Besides that, discussions with partner teachers were conducted to determine the essential problems needed in developing learning materials.

\subsubsection{Learner Analysis}

Learner Analysis namely examining student characteristics that are in accordance with the design and development of subject matter that has been determined in the curriculum analysis. These characteristics include the ability background and the level of cognitive development of students.

\subsubsection{Concept Analysis}

Concept analysis namely identifying, descripting, and systematically arranging relevant topics to be taught based on curriculum analysis.

\subsubsection{Task Analysis}

Task analysis is to identify the main ability needed in the appropriate learning with the junior high school mathematics curriculum based on concept analysis.

\subsubsection{Specifications of Learning Objectives}

Specifications of learning objectives, namely discussing the results of task analysis and topic analysis into specific learning objectives, expressed by behavior.

\subsection{Design}

\subsubsection{Criterion-tes Constructions}

Criterion-tes Constructions is to guide the results of the task analysis outlined in the specifications of the learning objectives.In this study the reffered test is test of student learning outcomes in mathematical problem solving abilities.To design a test of student learning outcomes, the questions and scoring references are made.The scoring used is the benchmark reference assessment with reason oriented to the level of students' ability to the subject to be tested, so that the score obtained shows the percentage of their ability.

\subsubsection{Media Selection}

Media selection is determining the right media in presenting learning material.This media selection process is adjusted to the results of the task analysis and analysis of the concepts and characteristics of students.

\subsubsection{Format Selection}

Format Selection is closely related to media selection.
Later in this sourcebook, diferent formats are identified which are suitable for designing instuctional materials for teacher training.

\subsubsection{Initial Design}

Initial design is the writing of the pre design activities that must be carried out before the experiment is carried out. The initial draft that will involve student activities are Learning Implementation Plans, Teacher Books, Student Books, Student Worksheets, Mathematical problem solving ability tests and self-regulated learning questionnaires.

\subsection{Development}

\subsubsection{Validation Testing}

Validation testing is a technique to get improvement suggestions as well as an assessment of the learning instrument that have been produced at the design stage. The learning instrument in question is all instrument that have been developed at the design stage (Draft 1).

\subsubsection{Development Testing}

The Development testing of the research instrument is to produce a good research instrument, in the mean that it is valid and feasible to use during the experiment.

\subsubsection{Field Test}

Field test namely the learning instrument that have been developed will be tested on the class which is the place of research that aims to see the effectiveness of the learning instrument that have been developed which are measured from: (1) Achievement of students' classical completeness; (2) the ability of the Teacher to manage learning; (3) positive response of students.From the three conditions above, if one is not fulfilled, the role of learning is not yet effective.If the results of data analysis in the first development testing result in a learning tool that has not been effective and the ability to solve problems and self-regulated learning of students has not reached the specified completeness, then the next test will be second development testing.

\subsection{Disseminate}

The disseminate stage is the dissemination of the final instrument in the partner school in class VII on the instrument of One Variable Linear Equation and Unequation.

\section{Results and Discussion}

Based on the formulation of the problems and research questions submitted in the previous section, then based on the data obtained from the results of first development testing and II it will be known whether the formulation of the problem and the proposed research questions have been answered or not.The results of data analysis obtained from first and second development testing show: (1) learning instrument developed are valid; (2) learning instrument based on scientific learning developed practically; (3) learning based on scientific developed effectively; (4) there is an improve in students' 
mathematical problem solving ability through learning instrument based on the scientific learning developed; and (5) an improve in self-regulated learning.

Based on the above research questions submited in the previous section, and data obtained from the results of first and second development testing, it will be known whether the problem formulation and the proposed research questions have been answered or not. The results of data analysis obtained from the results of first and second development testing show: (1) learning instrument with models problem based learning developed valid; (2) learning instrument with the model problem based learning developed practically; (3) learning instrument with the model problem based learning developed effectively; (4) there is an increase in problem solving ability by using learning instrument with the model problem based learning developed. (5) there is an increase in self-regulated learning by using learning instrument with the model problem based learning developed.

\subsection{Validity of Scientific Learning Instrument Developed}

Based on the results of the validation of the learning instrument based on the scientific learning developed, it was found that the Learning Implementation Plan, Student Book, Teacher Book and Student Worksheet were declared valid or had a good degree of validity. Furthermore, the results of the validation of the mathematical problem solving ability test and the selfregulated learning questionnaire are also valid or have a good degree of validity.This shows learning instrument based on scientific learning developed both Learning Implementation Plans, Teacher Books, Student Books, Student Worksheets, mathematical problem solving ability tests and self- regulated learning questionnaires that have fullfil the criteria validity.

Validity criteria were obtained through expert assessment of learning instrument developed using saintific learning. The availability of valid learning instrument is caused by several factors, including: (1) the learning instrument developed have fulfilled the content validity. This means that in the development of learning tools based on scientific learning in accordance with the demands of the existing curriculum that is related to core competencies and basic competencies that must be achieved by students in learning activities that are follow to the material or subject matter provided.This is appropriate to Arikunto (2009: 57) [9] which states that, good content validity is when a learning instrument can measure certain specific goals that are parallel to the material or the content of the lesson given.The validity of this content, also often referred to as the validity of the curriculum.

Then, (2) learning instrument based on the scientific learning developed have fulfilled the construct validity. It means, in the development of learning instrument based on scientific learning in suitable with the concepts and indicators of mathematical problem solving abilities which are then combined with learning instrument based on the scientific learning developed. Learning instrument based on the scientific learning developed were developed complementary between the learning implementation plan, the Teacher's Book, the Student Book, and the Student
Worksheet used to measure mathematical problem solving abilities. Fulfillment of good aspects of validity as stated above, Akbar (2013: 152) [10] adds that, high validity is obtained through validation tests on developed learning instrument.

As stated in the development research conducted by Sinaga (2007), [11] where based on the results of expert validation and revisions that have been made it is obtained that, the development of learning models and instrument in the form of learning implementation plans, teacher books, student books, and student worksheets is valid and can be applied. Furthermore, the same thing was also expressed through the results of Syahbana's research (2012: 21), [12] which is based on the results of the development of learning instrument that have fulfilled valid criteria.

Then according to Nieveen (2007), [13] "Another characteristic of high-quality interventions is that endusers (for example the learners and learners) largely compatible with the developers' intentions. If these conditions are met, we call these interventions practical.

The validity of the learning instrument is illustrated by the results of the validator's assessment that all validators state both the content (according to the curriculum), the construct (according to the characteristics / principles of learning) and language (in accordance with the prevailing language rules namely improved spelling). Based on the results of research and supporting research, it can be concluded that learning instrument based on the scientific learning developed have fullfiled the criteria of validity as expected.Thus the learning instrument based on the scientific approach developed can be used.

\subsection{Practicality of Saintific Learning Instrument Developed}

The results of the assessment of the practicality of the learning instrument are obtained from the expert / practitioner assessment stating that the learning instrument developed can be used with little revision or without revision. Based on the results of expert assessments, the components of learning instrument developed in the form of Learning Implementation Plans, Teacher Books, Student Books, Student Worksheets, problem solving ability tests and self-regulated learning questionnaire are practical / can be used with minor revisions.

Practicality is that the learning instrument that are prepared consider the ease. Ease in the meaning of the learning instrument that are arranged are easy to understand and also easy to implement or use. (Nieveen, N. 2007: 127-128). [13]

For practicality assessment, then from the observations of the feasibility of learning instrument in the class included in the high category $(3 \leq \bar{P}<4)$ or very high $(4 \leq \bar{P} \leq 5)$ and the instrument is considered to be good if it has a reliability coefficient of 0.75 or $75 \%$. This second aspect of practicality assessment is explained as follows.

Practical criteria that are reviewed from the feasibility of the learning instrument in this study, have also fulfil the practical criteria.In the first trial and trial II the implementation of the learning instrument had met the established criteria, namely having achieved a very high 
category $(4 \leq \bar{P} \leq 5)$, and for the reliability of the learning instrument with the scientific learning in experiment I and experiment II also had achieving the specified category, namely the instrument can be considered to be good because it has reached a reliability coefficient of 0.75 or $75 \%$. Indeed in the first development testing, some students were still unfamiliar with the use of learning instrument with a scientific learning demanding student activities, but in subsequent trials students became more accustomed and happy.

Practical learning intrument are obtained due to several things. Many things that support practicality are: (1) The Learning Implementation Plan that is prepared is easy to understand and easy to use by teachers and students in the learning process; (2) Steps with a scientific learning are easily implemented by the teacher; (3) Student Worksheets that are prepared are easily understood by students because the instructions given are clear, the writing is easy to read, and the pictures and tables used are easy to understand and interesting; (4) Teacher Books and Student Books which are arranged in easy-to-understand sentences and learning materials are presented systematically; and (5) The sentence of the questions and statements on the test of students' problem solving abilities is not ambiguous (has more than one meaning) and the workmanship commands are easy to understand. And the self- regulated learning questionnaire contains statements that are easily understood by students.

Based on the description above it can be concluded that the learning instrument developed with the scientific learning have fulfilled practicality as expected. Thus the learning instrument through the scientific learning are developed easily and can be implemented by teachers and students.

\subsection{The Effectiveness of Scientific Learning Instrument Developed}

In determining effectiveness it can be seen from three aspects, they are: 1) classical learning completeness; 2) students' positive response to the learning instrument component based on the scientific learning developed;and 3) the ability of teachers to manage learning in good categories. The aspects of each of the effective categories above are explained as follows.

\subsubsection{Completeness of Classical Student Learning}

Based on the test results of students' problem solving abilities seen from the first development testing there is a percentage of completeness of $62.3 \%$ and second development testing there is a percentage of completeness 88\%. This shows that students' problem solving abilities increased from first and second development testing.

The increase in mathematical problem solving ability can be studied theoretically by paying attention to the principles, characteristics, and learning steps with the scientific learning applied in this study.The application of discovery learning model with the scientific learning has several advantages, where if these advantages can be maximized in classroom learning it will be able to improve students' mathematical problem solving skills. These advantages can be seen from the principles, characteristics and steps of learning.
When associated with the characteristics of discovery learning models according to Hosnan (2014: 284) "the main characteristics of learning to find are (1) exploring and solving problems to create, combine and generalize knowledge (2) student-centered; (3) activities to incorporate new knowledge and existing knowledge”. This conclusion was also emphasized by Kamal (2015) [14] who stated that "with the Scientific learning students will be more challenged to be able to solve an existing mathematical problem". By paying attention to these main characteristics, it is clear that the application of the scientific learning can improve students' mathematical problem solving ability. Besides that, ongoing learning is student-centered so that students can truly connect new knowledge to pre-existing knowledge.

The results of this study are suitable with the research conducted by Dewi (2014) [15] where devices used with scientific learning can improve students' problem solving and reasoning abilities. Thus the scientific learning has the potential to improve students' mathematical problem solving.

Based on the results of the research and support of the previous research above, it can be seen that the scientific learning-based learning instrument developed can help students achieve classical learning completeness. Thus it can be concluded that the use of learning instrumentbased on the scientific learning developed has met the effective criteria in terms of classical student learning completeness.

\subsubsection{Student Response}

The criteria for students' response to the learning instrument developed were fulfilled if $\geq 80 \%$ of students gave a positive response to the components of the instructionalinstrumentdeveloped. Based on the results of the analysis of the results of the first and second develovement testing data, it was found that the average percentage of student responses in eachdevelovement testing was positive. This means that students feel helped and happy with the problem-based teaching instrumentdeveloped. Student responses given to each develovement testing have reached the predetermined criteria category, namely $\geq 80 \%$. This shows that the learning instrument based on the scientific learning developed have met the effective criteria in terms of student responses.

Similiar with the results of the above studies, scientific learning is based on the premise that problematic situations that are confusing or unclear will arouse students' curiosity and make them interested in investigating. In other words, learning instrument based on scientific learning that are developed can arouse students' interest in learning so that learning activities become effective.

According to Daryanto (2013) [16] learning is a process of change that is a effort process that is carried out by a person to obtain a new behavior change as a whole as a result of interaction with the environment. This is because the learning process is complex, where students determine whether they will learn or not. So, the actions / responses given by students to the stimulus in the form of teaching as an activity can be categorized into two things, namely a positive response to learning (listening, reading, writing, discussing / asking) and a negative response (other actions that are not relevant). A positive response indicates that 
students are willing to follow the learning process. Positive responses given by students are caused by teacher has provided a stimulus in the form of feedback and reinforcement that is appropriate to the characteristics of students after learning the situation of class.

Based on the characteristics of students, the teacher makes a learning plan that contains activities carried out by students, time, and evaluation that are adjusted to the learning based on scientific learning. The teaching program is also outlined in learning instrument such as teacher books, student books, learning implementation plans, and student worksheets as a guide for students and teachers in directing students to obtain solutions to problems and achieve learning goals. Therefore, a teacher must prepare a mature and accurate learning plan so that the teacher will be able to predict how much progress will be achieved. In other words the teacher is a very decisive component in implementing a learning strategy.

This is reinforced by the results of research Sinaga (2007) [11] states that "the criteria that is set to determine that students have a positive response to the learning device developed if the number of students who give a positive response is greater or equal to $80 \%$ of many subjects researched for each field experiment".

Based on the exposure of research results and supporting research, it can be concluded that the components of learning instrumentbased on the scientific learning developed contribute positively to students' responses to learning.

\subsubsection{Teacher's Ability to Manage Learning}

The last criterion of effectiveness in terms of the teacher's ability to manage learning has met the effective criteria. In the first and second experiment the ability of teachers to manage learning met good categories $(3,50 \leq$ teacher ability $\leq 4,50$ ).

Based on the results of data analysis results of the first and second development testing, it was found that the average value of the teacher's ability to manage learning in each trial was in a good category $(3.50 \leq$ teacher ability $\leq 4.50$ ) if referred to the teacher's ability criteria manage the learning set out in chapter III.

According to Hosnan (2014: 39) [2] "teacher activity in learning is providing learning resources, encouraging students to interact, asking interaction results questions, giving scaffolding, encouraging students to dialogue, confirming the understanding gained and encouraging students to reflect on their learning experiences". From the explanation above, it can be concluded that the application of discovery learning with the scientific learning approach can improve the teacher's ability to manage learning.

Based on the description above it can be concluded that the learning intrument based on the scientific learning developed have met the criteria of effectiveness as expected.

\subsection{Improvement of Students' Mathematical Problem Solving Ability}

One of the goals obtained from the development of learning instrument in this study is to improve students' mathematical problem solving ability. Syahputra and Surya (2017) [17] stated that "In the Curriculum 2013, the learning is using the scientific method, multi-strategy, multimedia, adequate learning source and technology, and utilizing the environment as a learning resource.

Learning Model that used is problem based learning. This model is appropriate to improve student's mathematical problem solving ability. In the learning process, student's activity is started with observation, then asking questions, trying, making networks, and analyzing. "This means that in the 2013 curriculum, learning uses scientific methods, multi strategies, multimedia, learning resources and adequate technology, and use of the environment as a learning resource. The learning model used is problembased learning. This model is suitable for improving students' ability to solve mathematical problems. In the learning process, student activities begin with observation, then asking questions, trying, networking, and analyzing. By using a scientific learning, the role of the teacher becomes very important that is to become a facilitator, the teacher must be able to direct or help students to determine what is known, what is needed to know and where they can find important information, so that students are able to understand for what and why they must learn. The learning process based on such scientific learning has a positive impact on the development of mathematical problem solving abilities and helps students develop intellectual discipline and skills needs to arouse curiosity and seek answers to their curiosity.

Appropriate with the research conducted by Dewi (2014) [15] where the instrument used with the scientific learning can improve students' problem solving and reasoning ability. Thus discovery learning model with scientific learning has the potential to improve students' mathematical problem solving.

Based on the results of the analysis of the improvement of students 'mathematical problem solving abilities in the first development testing of the students' mathematical problem solving is $62.3 \%$. Then in the second development testing, the results of the average mathematical problem solving ability of students increased in the posttest is $88 \%$. Thus, there was an increase in the average of first and second posttest is $25.7 \%$.

Based on the explanation and data analysis of students' problem solving abilities above, it is known that scientific learning encourages students to be able to communicate the things that have been understood and whatever in their mind to build a knowledge acquired.

\subsection{Improvement of Self - Regulated Learning}

Based on the results of the self-regulated learning questionnaire data analysis in first and second development testing showed that self-regulated learning is improved or better. The improvement of self-regulated learningis seen from the average results of self-regulated learningquestionnaire filled by students, from an average of 79.09 to an average of 82.35. Improved self-regulated learningis also seen in each indicator of self-regulated learning, namely: (1) Learning initiative; (2) Diagnosing learning needs; (3) Regulate and control the progress of learning; (4) Setting learning targets and objectives; (5) Viewing difficulties as challenges; (6) Finding and utilizing relevant learning resources; (7) Selecting and 
implementing learning strategies; (8) Evaluating learning processes and results; and (9) Having self-concept. This shows that the use of learning instrumentbased on the scientific learning developed has an impact on improving self-regulated learning.

The results of Kamal's research (2015) [14] show that after the implementation of learning through the scientific in learning mathematics on trigonometric material in class X.3 of SMA Negeri 10 Banjarmasin, the self-regulated learning of mathematics learning in class X.3 has begun to increase, this is evident from the observations of researchers and observers by assessing student activities, interview results and reinforced by giving questionnaires to students by referring to indicators of self-regulated learning, namely self-confidence, initiative, responsibility and motivation to learn, as a result students are able to demonstrate activities in mathematics learning that show improved self-regulated learningin students, after the implementation of the scientific learning in mathematics learning in class X.3 Banjarmasin 10 Public High School.

This is strengthened through the results of research conducted by Eliserio (2017) [18] which shows that "This research examines the relationship between self-regulated learning and mathematics achievement. The sample included 10 students enrolled in fourth grade at a small, private elementary school in the Midwest. During the third quarter of the school year, students were taught methods of learning mathematics through self-regulation. The grades were recorded before the implementation at the conclusion of the second quarter and again at the conclusion of the third quarter once self-regulation was implemented. A t-test was used to compare the mathematics scores. There was no significant difference between the second and third quarter mathematics grades. This is an important result as it differed from the findings in research".In other words, learning mathematics through guidance and individual learning strategies gives a better influence on the achievement of self-regulated learning.

From the description above it can be concluded that scientific learning and self-regulated learningdirects students to have independence and responsibility in learning, they are free and responsible for improving their knowledge in finding other learning resources.

\section{Conclusion}

Learning instrument developed are included in the valid category with an average total validity value of Learning Implementation Plans is 4.27, teacher books and student books are 4.496, and Student Worksheet is 4.37. So the mathematical problem solving ability test developed can be used or valid. And the questionnaire statement of the attitude of student learning independence with a significant level of $5 \%$, $d k=24$, obtained $t_{\text {table }}=1.71$. So the self - regulated learning questionnaire can be used or valid.

The developed learning instrument have met the practical criteria in terms of: (1) the expert / practitioner assessment states that scientific learning developed can be used with a slight revision; and (2) the feasibility of learning instrument has reached a high category in first experiment which is 3.82 and reaches a very high category in second experiment, which is 4.17 .

The developed learning instrument have met the effective criteria. Effective criteria in terms of: (1) classical learning completeness of students has reached $88.5 \%$ in second experiment; (2) positive student response is more than $80 \%$; and (3) the ability of teachers to manage learning obtain an average of 4.07 in the good category.

The improvement of students' mathematical problem solving abilities in the first development testing of the students' mathematical problem solving is 62.3\%. Then in the second development testing, the results of the average mathematical problem solving ability of students increased in the posttest is $88 \%$. Thus, there was an increase in the average of first and second posttest is $25.7 \%$.

The improvement of self-regulated learning is seen from the average results of self-regulated learning questionnaire filled by students, increased from an average of 79.09 to an average of 82.35 .

\section{Acknowledgments}

In this moment the writer would like to thank and give appreciation and gratitude to Mr. Suryono and Mrs. Soni for supporting the writing in terms of morale and meteril. The writer also gives so much thanks to all everyone who have gave helpsso writercan finish this paper.

\section{References}

[1] Rajagukguk, W. (2011). Efforts to Improve Students' Mathematical Problem Solving Ability by Implementing Bruner Learning Theory on Trigonometry Subjects in Class X Sma Negeri 1 Kualuh Hulu Aek Kanopan T.A. 2009/2010. ISSN 08530203VISI (2011) 19 (1) 427-442 www.iiste.org, ISSN 2222-1735 (Paper), ISSN 2222-288X (Online) Vol.8, No.6, 2017.

[2] Hosnan, M. (2014). Scientific and Contextual Approach in 21st Century Learning.Ghalia: Bogor.

[3] Surya, E., Sabandar, J., Kusumah, Y. \& Darhim (2013). Improving of Junior High School Visual Thinking Representation Ability in Mathematical Problem Solving by CTL. International Journal IndoMS. J.M.E Vol. 4 No. 1, pp. (113-126), January 2013.

[4] Permendikbud Nomor 59 (2014). About the 2013 Curriculum of Madrasah Aliyah High School. 2014. Jakarta: Menteri Pendidikan Kebudayaan.

[5] Eviyanti, C., Surya, E., Syahputra, E., \& Simbolon, M. (2017). Improving the Students' Mathematical Problem Solving Ability by Applying Problem Based Learning Model in VII Grade at SMPN 1 Banda Aceh Indonesia. International Journal of Novel Research in Education and Learning, Available at: www.noveltyjournals. com ISSN 2394-9686Vol. 4, Issue 2, pp: (138-144), Month: March - April 2017.

[6] Suhery, D., Saragih, S., \& Syahputra, E. (2013). Improving Students' Mathematical Problem Solving and Self-Reliance Ability Through Problem-Based Learning. Jurnal Mathematics Paedagogic ISSN 2087-1783 Vol. III No. 2 Maret 2013.

[7] Atsnan, M. F. dan Gazali, R. Y. (2013). Application of Scientific Approach in Junior High School Mathematics Learning Class Vii Number Material (Fractions). Jurnal didaktik dalam Seminar nasional Matematika dan Pendidikan Matematika FMIPA UNY Yogyakarta, ISBN: 978-979 vol . 4 halaman 430-436, november 2013.

[8] Permendikbud Nomor 81 A. (2013). Curriculum Implementation. Jakarta :Menteri Pendidikan Kebudayaan.

[9] Arikunto, S. (2009). Educational Evaluation Basics. BumiAksara : Jakarta. 
[10] Akbar, S. (2013). Learning Device Instrument. Bandung: Remaja Rosda karya.

[11] Sinaga, B. (2007). Development of Mathematical Learning Models Based on Batak Culture-Based Problems (PBM-B3). Disertasi Program Pascasarjana Universitas Negeri Surabaya, tahun 2007.

[12] Syahbana, A. (2012). Development of Contextual Based Learning Tools to Measure Mathematical Critical Thinking Ability of Middle School Students. Edumatica, (Online), Vol. 02 No. 02, Oktober 2012, ISSN:2088-2157, (http://online-journal.unja.ac.id, diakses 9 September 2015).

[13] Nieveen, N. (2007). An Introduction to Education Design Research. China: The east China Normal University.

[14] Kamal, S. (2015) Implementation of a Scientific Approach to Improve Mathematics Learning Independence. Jurnal Pendidikan Matematika, ISSN 2442-3041. Vol. 1, No.1, Januari - April 2015.
[15] Dewi, N. D. P. (2014). Development of Mathematics Learning Devices with a Scientific Approach Oriented Information and Communication Technology to Improve Students' Problem Solving and Reasoning Capabilities. e-jounal Program Pascasarjana Universitas Ganesha, Vol 3 No.1 pp: (1-12), 2014.

[16] Daryanto (2013). Effective learning innovation. Bandung: Yrama Widya.

[17] Syahputra, E., \& Surya, E. (2017). The Development of Learning Model Based on Problem Solving to Construct High-Order Thinking Skill on the Learning Mathematics of 11th Grade in SMA/MA. Journal of Education and Practice www.iiste.org ISSN 2222-1735 (Paper) ISSN 2222-288X (Online) Vol.8, No.6, 2017.

[18] Eliserio, D. (2012). Self-Regulated Learning and Mathematics Achievement in a Fourth Grade Classroom. Digital Collections @ Dordt : Sioux Center, Iowa. 